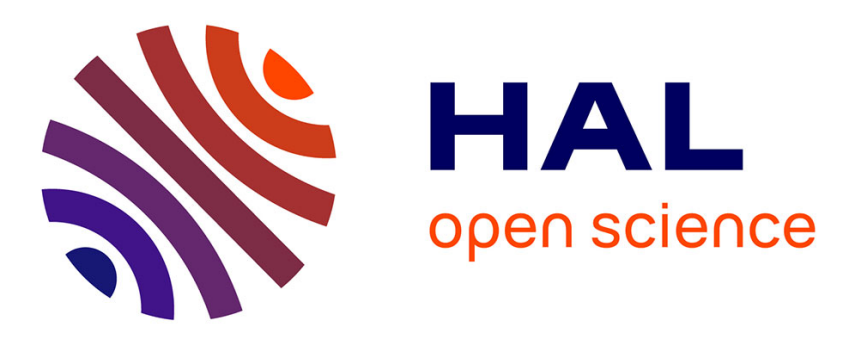

\title{
1 MWt bench model solar receiver test program
}

\author{
J. Gintz, D. Bartlett, R. Zentner
}

\section{To cite this version:}

J. Gintz, D. Bartlett, R. Zentner. 1 MWt bench model solar receiver test program. Revue de Physique Appliquée, 1980, 15 (3), pp.363-368. 10.1051/rphysap:01980001503036300 . jpa-00244738

\section{HAL Id: jpa-00244738 https://hal.science/jpa-00244738}

Submitted on 1 Jan 1980

HAL is a multi-disciplinary open access archive for the deposit and dissemination of scientific research documents, whether they are published or not. The documents may come from teaching and research institutions in France or abroad, or from public or private research centers.
L'archive ouverte pluridisciplinaire HAL, est destinée au dépôt et à la diffusion de documents scientifiques de niveau recherche, publiés ou non, émanant des établissements d'enseignement et de recherche français ou étrangers, des laboratoires publics ou privés. 


\title{
$1 \mathrm{MW}_{\mathrm{t}}$ bench model solar receiver test program
}

\author{
J. Gintz, D. Bartlett and R. Zentner \\ Boeing Engineering and Construction Company, P.O. Box 3707, Seattle, Washington 98124, U.S.A.
}

(Reçu le 15 septembre 1979, accepté le 18 octobre 1979)

\begin{abstract}
This report is an account of the design, checkout and solar testing of a cavity receiver using metal gas-in-tube heat exchangers. The design represents a scale model of a Brayton cycle solar electric plant receiver. The program span from initiation of design to test completion was 32 months. The DOE-Central receiver test facility was utilized in this inaugural test.

Tests involved controlled parameter investigations of heat balance, non-uniform heating and transients; and demonstrations of solar load following. Design thermal efficiency predictions were achieved.
\end{abstract}

Since 1974, Boeing Engineering and Construction Company (BEC) has been conducting studies and research in high temperature, gas cooled, solar central receiver concepts under direction of the Electric Power Research Institute. This continuing activity is illustrated in the program summary of figure 1. The initial contract, RP377-1, had as its objectives an examination of technical feasibility of the closed Brayton cycle concept, the development of a receiver conceptual design, and definition of critical technical problems. A receiver test program was developed which would progress in an orderly manner from a bench model, through an experimental plant, to a commercial size plant. Heat exchanger candidate materials were proposed and two metals were thermally cycled to simulate a 30 year operating lifetime.

The recommendations of that study were implemented in July, 1976, with the award to BEC of Contract RP377-2 for Design and Fabrication of a $1 \mathrm{MW}_{\mathrm{t}}$ Bench Model Solar Receiver (BMSR). Scaling parameters included : physical size, helium represented by air, and closed cycle operation by open cycle design. Tests of insulation materials and design configurations were conducted. Welded joint development tests were performed to derive the required high quality in heat exchanger panels. Subcontractors skilled in steel construction and superalloy work were retained for fabrication of the BMSR. In May, 1978, the $1 \mathrm{MW}_{\mathrm{t}}$ receiver was completed.

Hot flow testing was conducted to evaluate flow control, instrumentation, and to thermally cycle the BMSR. Functional tests included control system response, proof tests of the heat exchanger system and instrumentation circuit continuity. In 1977 BEC was awarded Contract RP377-3 for solar testing and data evaluation.

The receiver was configured for testing at the Department of Energy's Central Receiver Test Facility (CRTF) in Albuquerque, New Mexico; it arrived there in August, 1978. Activities at the test site involved elevating the BMSR and Air Supply System support skid to the $140 \mathrm{ft}$. test level and connecting supply piping, instrumentation and control data links. Figure 2 shows the receiver in place on the tower.

A series of cold flow checkout tests were conducted to verify operation of BMSR controls and continuity with the data acquisition system. These tests were followed by verification of heliostat targeting which involved individual and groups of heliostats. First solar heating was accomplished on October 27, 1978. The test program continued through March, 1979 with an interruption in early March to re-insulate the back cover of the BMSR. The test program was successfully concluded on March 24, 1979 with over $8 \mathrm{hrs}$. of one-day continuous operation at maximum outlet flowrate and temperature. Data evaluation and analysis of results is in progress with anticipated conclusion and publication of the program final report in March 1980.

The BMSR is of welded-steel-frame construction and is lined with a composite blanket-type insulation. An eight-sided configuration with a truncated conical back cover was adopted as shown in the artist's concept of figure 3 . 


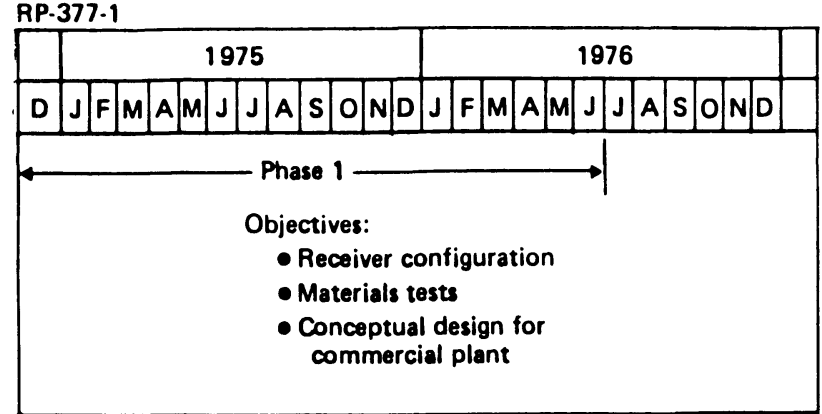

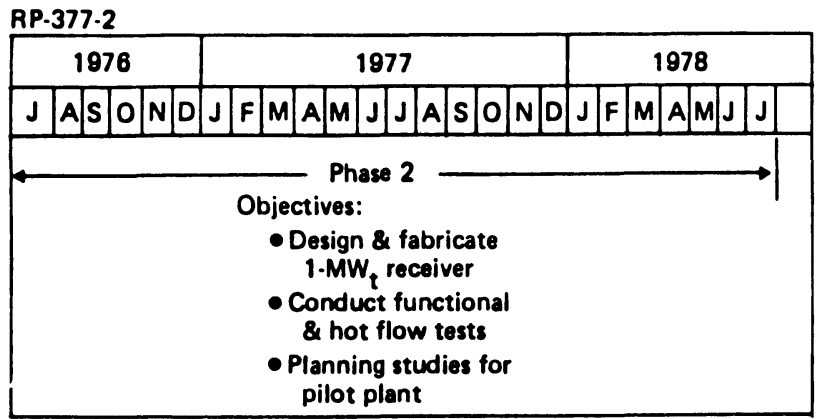

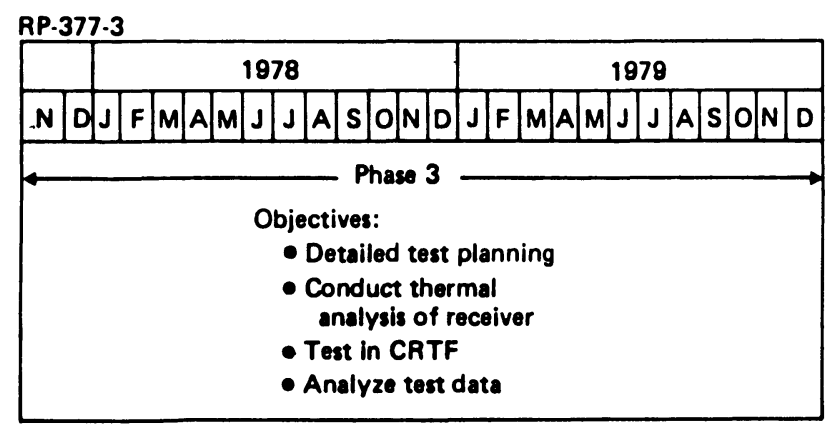

Fig. 1. - Program summary.

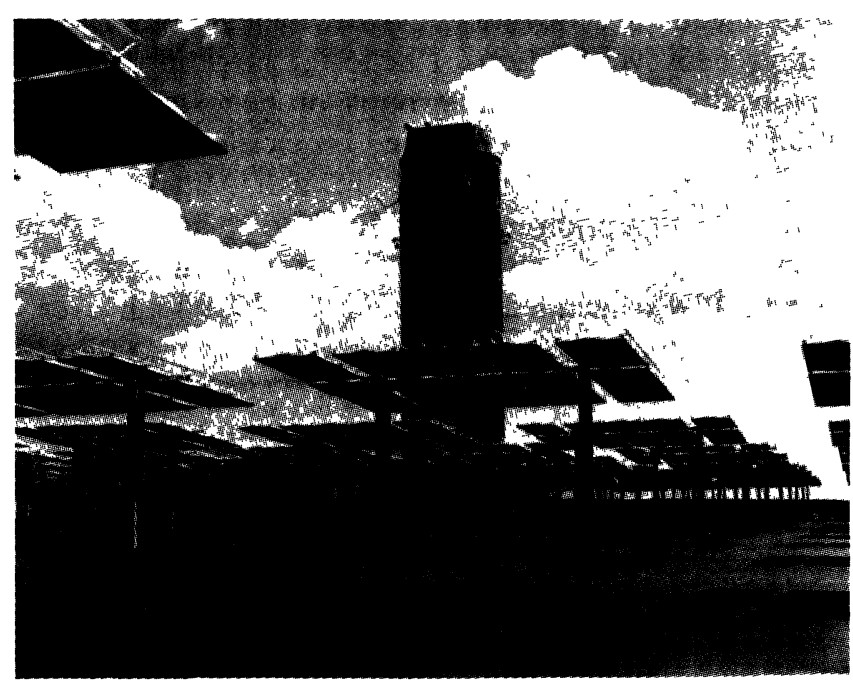

Fig. 2. - BMSR installed on test tower.
The aperture, 1.1 M (43 inches) in diameter, is shielded with a composite of zirconia board bonded over an alumina board substrate.

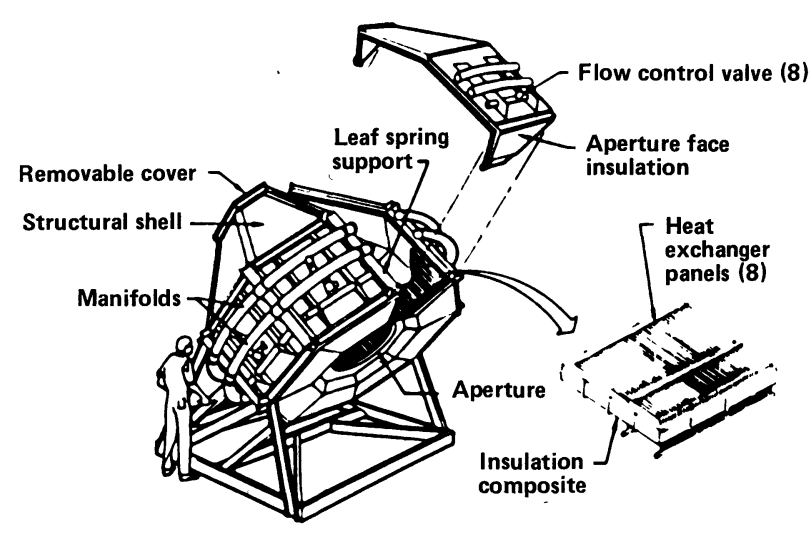

Fig. 3. - Bench model design concept.

Spectral properties of virgin and exposed insulation samples were obtained in the laboratory and a cavity insulation composite was designed, using a high temperature Saffil blanket for the innermost layer, over lower cost mineral wool. Tests were conducted with this configuration in a solar simulation facility at BEC. The insulation composite proved acceptable.

The heat exchanger system comprises elements inside and outside of the cavity. The external elements consist of stainless steel inlet and outlet manifolds, each connecting to eight headers. Within the cavity are eight heat exchanger panels as shown in figure 4. The panels consist of 54 tubes each, in a twopass configuration. The tubes are $0.51 \mathrm{~cm}(0.20 \mathrm{in})$ inside diameter, the heated length is $128 \mathrm{~cm}$ (50.5 in). Inconel 617 has been selected for this application.

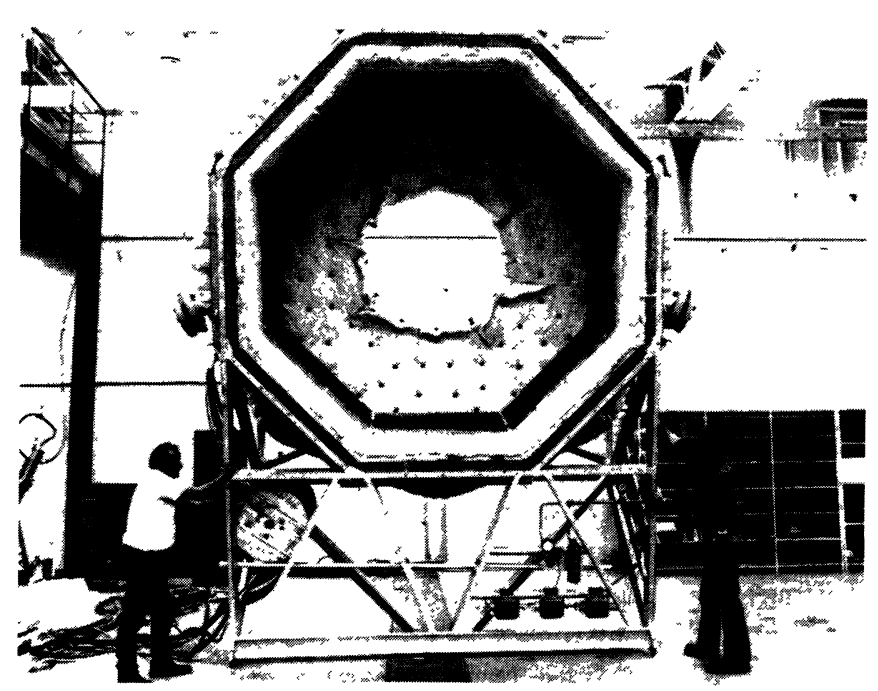

Fig. 4. - Bench model receiver with back cover removed. 
Gas flow in the heat exchanger system is controlled by valves located at the panel inlet headers. The gas is $538^{\circ} \mathrm{C}\left(1000^{\circ} \mathrm{F}\right)$ at this point, well within the capability of off-the-shelf valves. The BMSR thermal design includes automatic regulation of air outlet temperature to a pre-selected constant level. It accommodates changing solar thermal input and inlet gas temperature and maintains constant outlet temperature by adjusting gas flowrate. Pre-heated inlet air is provided by means of an air-to-air, tube shell recuperator which utilizes the hot exhaust gas from the BMSR to condition compressed air from a group of four diesel driven screw compressors. Equilibrium temperatures for the BMSR at full flow and maximum solar input are $538^{\circ} \mathrm{C}\left(1000{ }^{\circ} \mathrm{F}\right)$ air inlet and $816^{\circ} \mathrm{C}$ $\left(1500^{\circ} \mathrm{F}\right)$ air exhaust. The components of the test system are shown installed in the test tower at CRTF in the photograph of figure 5 . The diesel driven compressors, not shown, are located at ground level and supply air through facility interconnect piping.

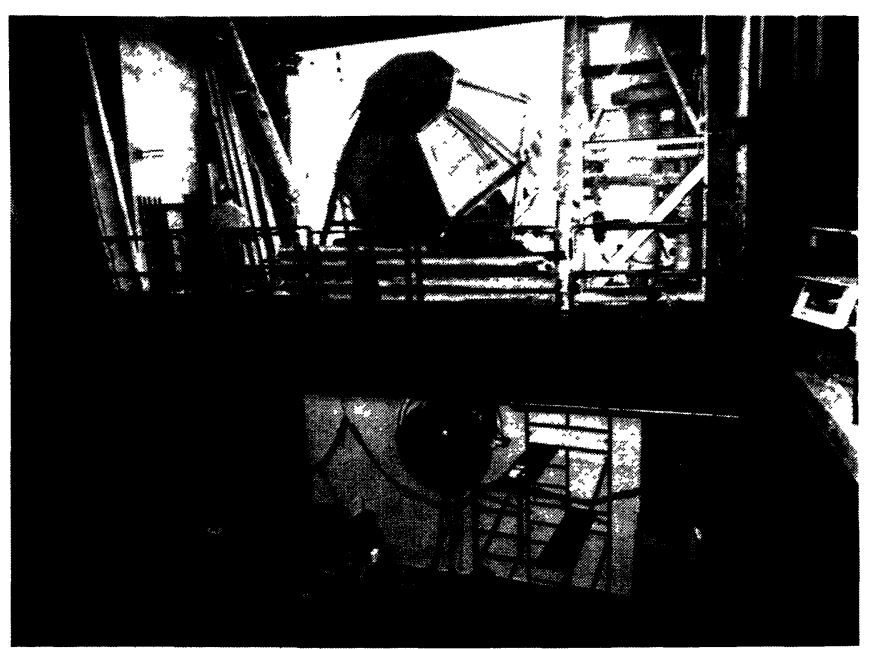

Fig. 5. - Test system components installed in tower at CRTF.

The BMSR test plan called for five types of controlled parameter tests and three types of demonstration tests. These are illustrated in figure 6 . The number of test runs planned for each category, and the actual runs performed are also shown. Equilibrium heat balance and thermal conversion efficiency was determined at several sets of conditions, starting at low solar input $(\approx 500 \mathrm{~kW})$ and gas inlet/outlet conditions of $340^{\circ} \mathrm{C} / 620^{\circ} \mathrm{C}\left(644^{\circ} \mathrm{F} / 1150^{\circ} \mathrm{F}\right)$. As experience was gained with the system, solar power levels were increased to the full rating of $1000 \mathrm{~kW}$.

Non-uniform heating tests involved changing from an even distribution of heliostats to a heavily onesided field arrangement to evaluate the cavity's ability to redistribute non-symmetric heating loads caused by cloud passage.

Restricted flow testing was planned to show that

\begin{tabular}{|cl|c|c|}
\hline & & $\begin{array}{c}\text { Planned test } \\
\text { runs }\end{array}$ & $\begin{array}{c}\text { Actual test } \\
\text { runs }\end{array}$ \\
\cline { 3 - 4 } & & & \\
Controlled parameters tests & & 16 \\
Equilibrium heat balance & (EB) & 9 & 2 \\
Nonuniform solar input & (NI) & 3 & 2 \\
Restricted coolant flow & (RF) & 3 & 2 \\
Transient heat load & (TH) & 4 & 2 \\
Solar load following & (SF) & 1 & 1 \\
Demonstration tests & & & \\
Cold startup & (CS) & 3 & 2 \\
Emergency cooldown & (EC) & 3 & 3 \\
Solar load following & (SF) & 3 & 2 \\
\hline
\end{tabular}

Fig. 6. - Solar test plan.

seven panels could carry the cavity heat load when the flow was severely restricted in the eighth panel.

Transient heat load tests simulated the effects of cloud passage; and solar load following demonstrated the ability to maintain constant outlet temperature over prolonged periods by manipulating air flow and solar input.

Demonstration tests involved repetition of solar load following to gain operational experience in varying degrees of cloud cover. In reality, much solar load following experience was gained in the earlier EB test series because of weather conditions. Cold startup tests were performed to show the warm-up response time and the capability of the system components to withstand severe thermal gradients. Emergency cool down simulated an abrupt termination of solar input, and later in the program, an evaluation of component thermal soakback when solar input and coolant gas flow were simultaneously terminated.

In several cases the number of test runs completed were less than planned. It was found that the pre-test selection of low input power level $(500 \mathrm{~kW})$ combined with maximum gas outlet temperature $816^{\circ} \mathrm{C}$ $\left(1500^{\circ} \mathrm{F}\right.$ ) was difficult to achieve within the regulation capability of the Air Supply System.

Figures 7 and 8 summarize the tests completed. Equilibrium heat balance testing involved solar inputs from $650 \mathrm{~kW}$ to $1100 \mathrm{~kW}$. In the early tests, gas outlet temperatures were constrained to $620^{\circ} \mathrm{C}(1150 \mathrm{oF})$; thus tests EB-1, EB-4 and EB-7 were completed before proceeding to more severe thermal environments.

\begin{tabular}{|l|l|c|l|}
\hline Completed tests & Solar input (kW) & Outlet temp. $\left({ }^{\circ} \mathrm{F}\right)$ & Features \\
\hline EB-1 & 650 & 1,150 & \\
EB-2 & 640 & 1,300 & \\
EB-3 & 710 & 1,500 & \\
EB-4 (3 tests) & 620 to 700 & 1,155 & Heat balance \\
EB-5 & 800 & 1,300 & at thermal \\
EB-6 & 840 & 1,500 & condibrium \\
EB-7 (2 tests) & 830 to 980 & 1,150 & \\
EB-8 (3 tests) & 910 to 1,030 & 1,300 & \\
EB-9 (3 tests) & 970 to 1,100 & 1,500 & \\
\hline
\end{tabular}

Fig. 7. - Equilibrium solar tests. 


\begin{tabular}{|c|c|c|c|}
\hline Completed tests & Solar input (kW) & Outlet temp. $\left({ }^{\circ} \mathrm{F}\right)$ & Features \\
\hline $\begin{array}{l}\text { NI-1 } \\
\text { NI-2 }\end{array}$ & $\begin{array}{l}775 \\
840\end{array}$ & $\begin{array}{l}1,150 \\
1,300\end{array}$ & $\begin{array}{l}\text { Transition } \\
\text { from uni- } \\
\text { form to east } \\
\text { side solar } \\
\text { input }\end{array}$ \\
\hline $\begin{array}{l}\text { TH-2 } \\
\text { TH-4 }\end{array}$ & $\begin{array}{l}1,050 \\
1,000\end{array}$ & $\begin{array}{l}1,300 \\
1,500\end{array}$ & $\begin{array}{l}\text { Controlled } \\
\text { transients }\end{array}$ \\
\hline $\begin{array}{l}\text { RF.2 } \\
\text { RF.3 }\end{array}$ & $\begin{array}{r}830 \\
1,000\end{array}$ & $\begin{array}{l}1,300 \\
1,300\end{array}$ & $\begin{array}{l}\text { Restricted } \\
\text { flow through } \\
\text { panel } 3\end{array}$ \\
\hline $\begin{array}{l}\operatorname{CS} 2, \cdot 3 \\
E C 1,-2,-3\end{array}$ & $\begin{array}{c}1,000 \\
750 \text { to } 1,000\end{array}$ & $\begin{array}{l}1,300 \text { and } 1,500 \\
1,150 \text { and } 1,500\end{array}$ & $\begin{array}{l}\text { Simulated } \\
\text { pilot plant } \\
\text { startups } \\
\text { and } \\
\text { shutdowns }\end{array}$ \\
\hline SF-2 (3 tests) & 950 to 1,100 & 1,500 & $\begin{array}{l}\text { Solar load } \\
\text { following }\end{array}$ \\
\hline
\end{tabular}

Fig. 8. - Controlled variables tests.

Non-uniform heating tests were also conducted in the same way to preclude the possibility of early receiver damage. As confidence was gained with the receiver's ability to survive thermal transients and non-uniformities the other controlled parameter tests were started at higher power inputs. The final solar load following tests involved one day of over $8 \mathrm{hrs}$. run time with a total of 106 heliostats in use at days end.

The results of an equilibrium heat balance test are shown in figure 9. The panel heat transfer and calorimeter measurements have been normalized to average values derived in performance of the test. A nonuniformity in panel heat transfer characteristics from top-to-bottom of the BMSR is apparent; the uppermost panels carrying a greater portion of the heat load. The calorimeter data shows that the cavity is effective in levelizing the solar input providing an even distribution of energy to each of the eight receiver bays.

Figure 10 shows similar data for the non-uniform solar input test. Again, the variation in individual panel heat load from bottom to top is evident. The panel heat transfer remained essentially unchanged as the heliostat field was shifted from a symmetric to east-side biased configuration, demonstrating the capability to distribute the heat load evenly within the cavity.

Figure 11 demonstrates the capability to maintain a constant outlet temperature when the gas flow in one panel is severely restricted. The initial outlet setpoint was $704^{\circ} \mathrm{C}\left(1300^{\circ} \mathrm{F}\right)$ for all eight panels. As the setpoint for panel 3 was increased, the flow control valve closed which caused a corresponding increase in panel 3 temperature and assumption of a portion of panel 3 heat load by the other panels.

Thermal performance predictions of BMSR characteristics were made by computer modeling. A

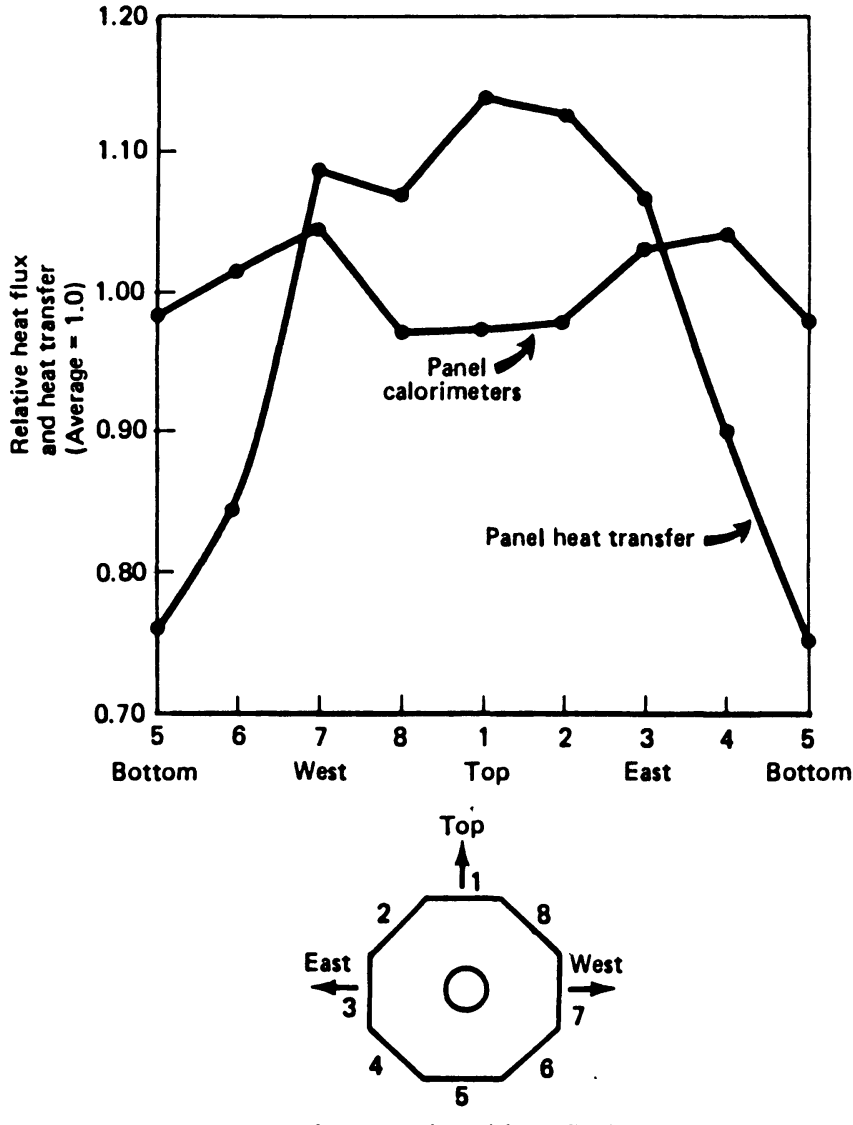

Aperture viewed from field

Fig. 9. - Test results equilibrium heat balance.

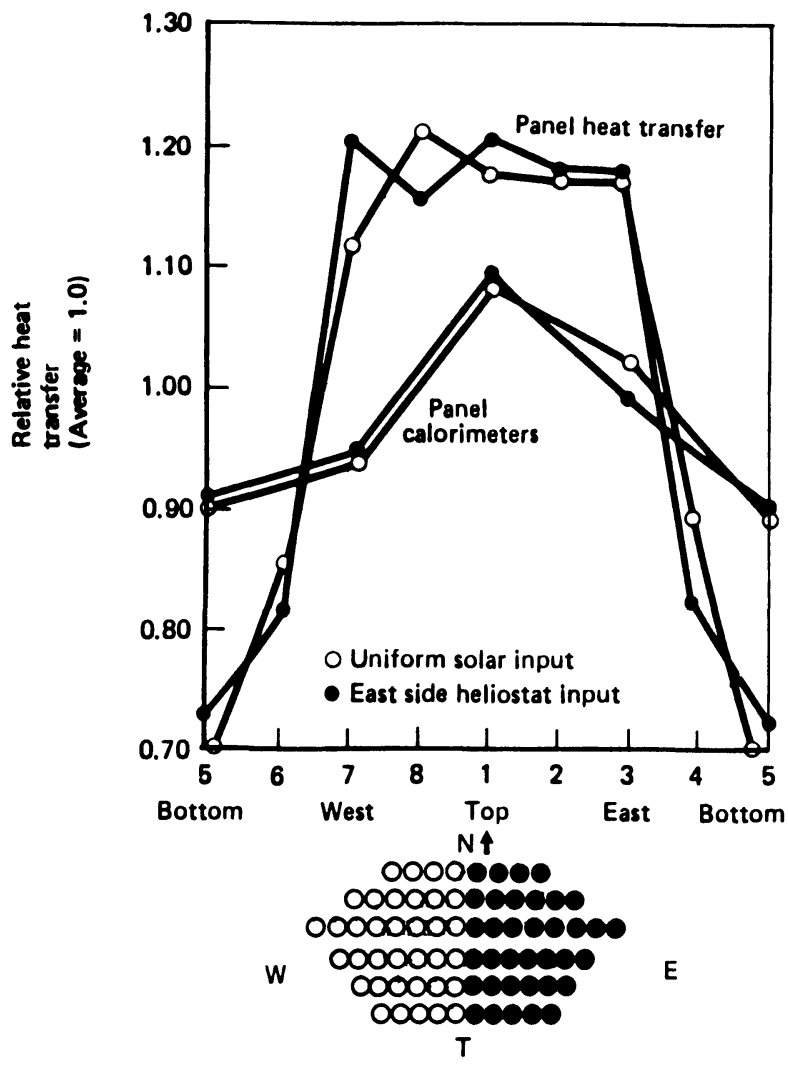

Collector field plan view

Fig. 10. - Test results non-uniform input. 


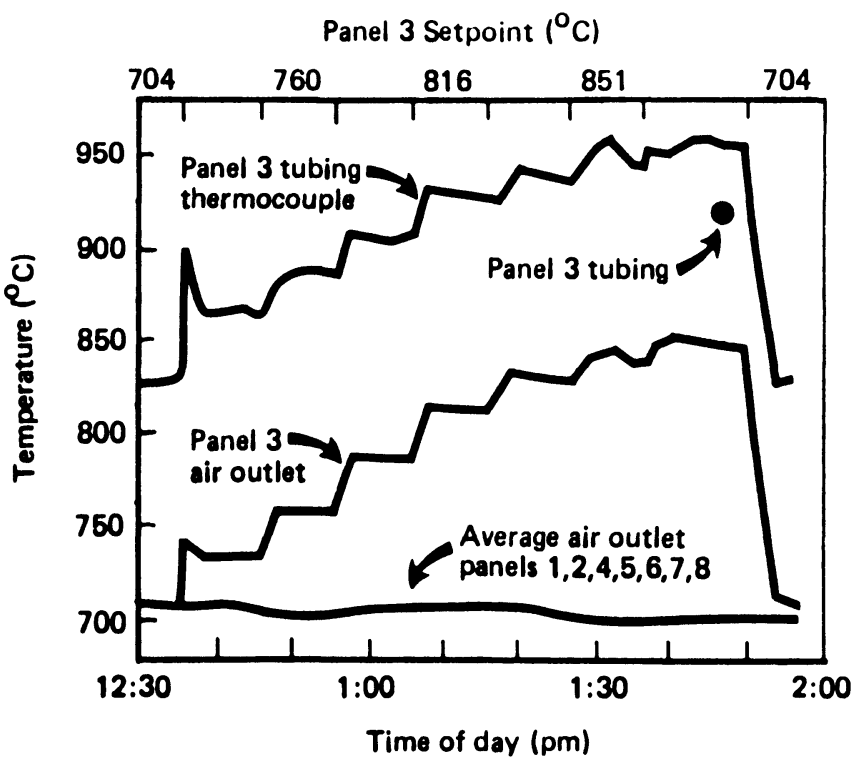

Fig. 11. - Test results restricted coolant flow.

transient analysis was used to predict coolant flow rate, tubing and insulation temperatures, panel heat transfer and cavity losses due to conduction, radiation, reflection and convection. The analytical results were compared with test data and it was found that in test, heat transfer of several panels was below expectations. Artificial heat sources were added to the model to force correlation of panel heat transfer predictions with test results and producing a reasonable match of tubing and insulation temperatures. The heat sources represented losses from the cavity and were attributed to a convection mechanism since radiation and conduction losses had been measured and calculated from test data.

A convection mechanism, shown in figure 12, was postulated for the BMSR to account for the unexpected thermal losses. An approximation of the loss was derived analytically using first order fluid mechanics and the measured aperture rim velocity. A large portion $(>1 / 2)$ of the aperture area must be active in the air exchange process and the exit temperature must be $\approx 177^{\circ} \mathrm{C}\left(350^{\circ} \mathrm{F}\right)$ to substantiate this analysis.

There is a large, $\pm 7 \%$, scatter in the thermal efficiency data for the seven full power test cases. Even though the pre-test assessment of combined solar input and thermal output measurements was $\pm 6.7 \%$, it was hoped that systematic errors could be reduced by pre-test instrument calibrations and the use of direct measurements of solar flux in the region of the receiver during tests.

The receiver free convection mechanism is of continuing interest. First, the relative thermal output of the eight receiver heat exchangers is nearly equally unbalanced in all seven sets of test data, similar to figure 9. Significant differences in ambient wind speed and direction during these test cases do not produce

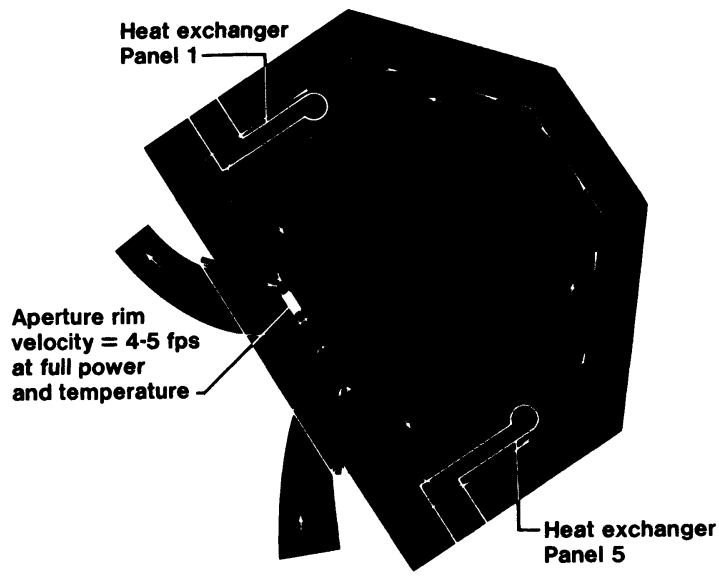

Fig. 12. - Assumed path of free convective airflow.

variations in the internal heat load distributions. This means that the internal cavity convection mechanism is repeatable. On the other hand, the net receiver heat loss due to free convection is very difficult to access because of the large uncertainty in the other test data. However, comparison of these seven test conditions with one another provides some insight. A three percent net loss due to the free convection airflow is consistant with the observed aperture rim airflow and the internal heat load unbalance mentioned above. A higher percentage of convective heat loss, such as $7 \%$ is not consistantly present in the test data. However, a few of the seven sets of full power test data could support this rate of convective loss. It remains distinctly possible that the internal convective re-distribution of solar heat is reproducible while the external circulation varies from test to test, producing rates of loss from 3 to about $7 \%$.

The solar testing data has been examined to find periods of time when the receiver was at nearly constant temperature with steady rates of heat transfer. A total of 17 of these quasi-steady state cases exist in the test data. Seven of the cases are at maximum operating temperatures and full solar power. Data from these full power test cases have been evaluated to determine the receiver solar input level and uncertainty. Consideration of analytical and experimental data for the test cases indicates that an uncertainty of $\pm 5 \%$ must be applied to this data.

These best estimates of receiver solar input for the 7 full power test cases are shown on figure 13 .

Receiver thermal output was continuously monitored during the solar tests. The flow-rate of air through receiver heat exchangers was measured along with inlet and outlet air temperatures. This data is supplemented by additional detailed temperature measurements of heat exchanger tube temperatures during operation. These data are tempered by an accessment of the temperature and flowrate measurement uncertainties associated with the air flowmeter, pressure and temperature sensors, and the test 


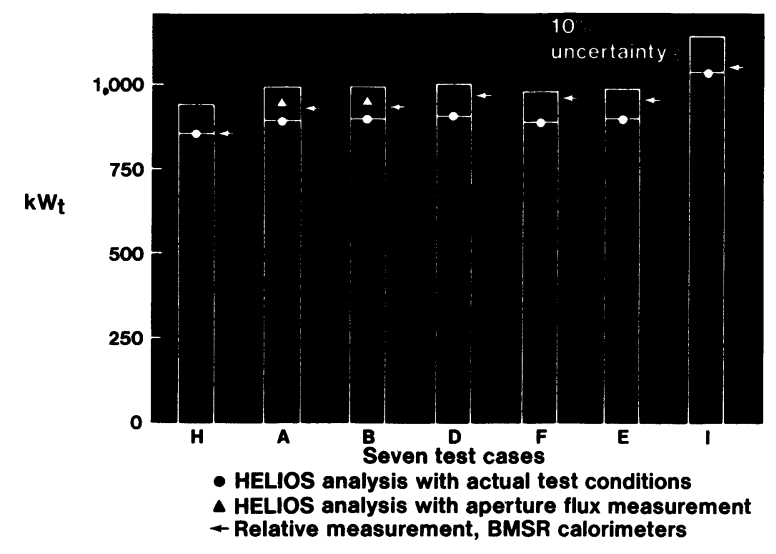

Fig. 13. - Receiver solar input.

data acquisition system. These considerations result in a $\pm 3 \%$ uncertainty being assigned to the receiver thermal output data. These data are shown on figure 14 for the seven full power test conditions.

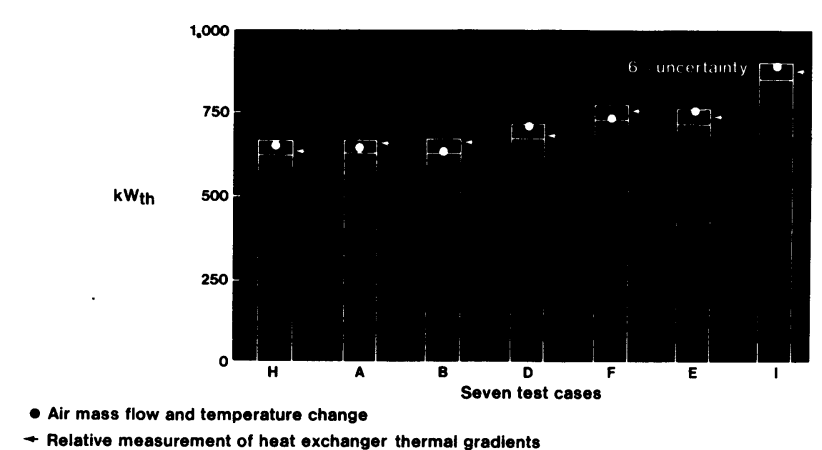

Fig. 14. - Receiver thermal output.

Receiver thermal performance is characterized by the ratio of its thermal output to its solar input, the receiver thermal efficiency. The nominal efficiency, based on the test data from all seven full power cases is $74 \%$. This is within the range of pretest predictions. The Bench Model Receiver was designed to simulate a $300 \mathrm{MW}_{\text {th }}$ solar receiver with a surround field. Commercial receiver designs with 80 to $85 \%$ thermal efficiency are expected when such details as aperture sizing, orientation and the location of receiver heat exchangers are optimized for the particular heliostat field configuration.

Conclusions. - Two unexpected results derived from the solar tests. First, convective heat transfer in a $1 \mathrm{MW}_{\mathrm{t}}$ receiver is significant, possibly increased by the inclined attitude of the aperture. Secondly, the cavity blanket insulation design deteriorated and was replaced during the course of testing. The solar flux impinging on the insulation surface was less than the design value of 425 suns.

The major achievements of this program were :

1) The design of gas-in-tube heat exchangers was verified and Inconel 617 alloy was operated successfully at temperatures greater than $927^{\circ} \mathrm{C}\left(1700^{\circ} \mathrm{F}\right)$.

2) The concept of automatic flow control of gas coolant was demonstrated.

3) The capability to redistribute solar input by reflection and radiation within a cavity receiver was verified.

4) An alternate cavity insulation, utilizing fibrous board products, exhibited the capability to serve as the first-incident-flux surface.

Testing of the BMSR provided data that verifies the concept for a commercial solar power plant. Valuable experience was gained in the control and operation of a central receiver solar thermal power system where all the components, excepting electric power generation, were assembled. 